\title{
THE ENVIRONMENT FOR ENTREPRENEURIAL ATTITUDES IN POPULATIONS OF RURAL AREAS IN POLAND FORMERLY OCCUPIED BY STATE-OWNED FARMS
}

\begin{abstract}
Renata MARKS-BIELSKA, Department of Economic Policy, University of Warmia and Mazury in Olsztyn, ul. Oczapowskiego 4/13, 10-719, Olsztyn, Poland, renatam@uwm.edu.pl (corresponding author)

Damian OPALACH, Department of Economic Policy, University of Warmia and Mazury in Olsztyn, ul. Oczapowskiego 4/13, 10719, Olsztyn, Poland, damian.opalach@uwm.edu.pl

Despite the lapse of 30 years since the state system transformation in Poland was started, the rural areas in Poland that used to be occupied by state-owned farms continue to experience many complex economic and social problems. The state reforms, which for example led to the dissolution of all state-owned farms (in Polish, Państwowe Gospodarstwa Rolne, PGR), have had a significant effect on the formation of the institutional system in rural Poland. The existence and then liquidation of PGR affected not only the financial standing of large populations but also instilled in many a sense of entitlement, leading to the so-called learned hopelessness. An investigation into entrepreneurial attitudes shows that as many as $71.60 \%$ of the respondents equate 'being entrepreneurial' with 'starting own business'. Despite the difficult situation on the labour market, only $12.35 \%$ of the interviewed persons have tried to start their own companies after state-farms were dissolved. The main determinant of such a low level of entrepreneurship among the respondents, in their opinion, was the lack of own funds, as this was indicated by $49.38 \%$ of the surveyed population. This attitude is also manifested in the answers concerning expectations towards public administration $-82.10 \%$ assumed that the state should be responsible for providing direct financial support. The results of this study into entrepreneurial attitudes as well as previous investigations among residents living in rural areas formerly occupied by state farms confirm marginal interest in starting business activity among these populations.
\end{abstract}

Keywords: entrepreneurship, rural areas, state-owned farms in Poland (PGR)

\section{INTRODUCTION}

For centuries now the notion of entrepreneurship and the figure of an entrepreneur have been assigned various roles in many different fields of science. Consequently, it has become impossible to define the two terms in a single, universal way (Cherukara, Manalel, 2011). Both the lack of a single, coherent definition and the need to employ an interdisciplinary approach in this research area give rise to many difficulties in the exploration of economic entrepreneurship (Baumol, 1990; Rispas, 1998). M. Novak (1993) defined entrepreneurship in societies emerging from the real socialism system, in countries like Poland, as a new way of thinking and acting, a moral and intellectual potential which determines one's willingness to start business activity. The economic activity pursued by individuals serves to replace the state as a source of goods and services supplied to the society (Novak, 1993). Local entrepreneurship is defined as economic activity stimulating the establishment of new companies, and as such contributing to the economic development and improved standard of living for the entire local community (Marks-Bielska, 2017).

Many researchers (e.g. Acs, Desai, \& Hessels, 2008; Audretsch, 2001; Baumol, 1990; Williams \& Vorley, 2015) have demonstrated that entrepreneurship is a key factor in the economic growth, both on the national and on the regional level (Huggins \& Thompson, 2016 ). Nonetheless, the occurrence of peripheral regions, perceived as 'entrepreneurial laggards', seems inevitable. Impediments they encounter in catching up with more competitive counterparts stem from an incompletely developed institutional system rather than from the absence of an opportunity to take action (Vaillant and Lafuente, 2007; Baumgartner et al., 2013).

The year 1989 marks the onset of a state transformation process in Poland. The previous, inefficient social and economic order was replaced by a new, much more efficient and effective system. This historic process which led to the fundamental economic, social and political transformations, created a new institutional framework for rural areas, including ones which in the past belonged to state-owned farms (PGR).

The implementation of a series of state reforms in the early 1990s, which inter alia caused the dissolution of all state-owned farms, had a significant influence on the shape of the institutional system developed for the growth of rural areas in Poland (Wilkin, 2007; Marks-Bielska, 2014). Being a set of interconnected and mutually affecting formal institutions (e.g. legal regulations, public organisations) and informal institutions (e.g. social attitudes, norms, traditions), the institutional system is one of the principal determinants of the socio-economic growth. Williams and co-authors (2017) showed that the most important contributor to the development of entrepreneurship is the interaction between

Copyright $\odot 2019$ The Authors. Published by Vytautas Magnus University. This is an open-access article distributed under the terms of the Creative Commons Attribution License (CC-BY 4.0), which permits unrestricted use, distribution, and reproduction in any medium, provided the original author and source are credited. 
formal and informal institutions in the country or in a given region. The process of privatisation in Polish agriculture focused mainly on changes in formal institutions (Milczarek, 2002). Moreover, a change in legal norms or the establishment of new organisations takes relatively little time, whereas a change in traditions, social attitudes or a way of thinking can last for many years or even generations (Wilkin, 2007).

Whatever model of implementing a system transformation is chosen, this change invariably causes considerable economic and social differences. In consequence, 'winners' and 'losers' appear. It can be claimed that 'winners' of the transformation of the Polish countryside are farm lessees or new owners of the farmland previously owned by the state farms, who improved their material status. 'Losers' are the vast majority of former PGR employees and their families, who lost their place of employment and whose material status deteriorated (Marks-Bielska, 2005). The way state-owned farms had operated for decades and how they were closed not only had an impact on the material status of farm workers, but also instilled in many a demanding attitude, a way of thinking leading to so-called learned helplessness. ${ }^{1}$ The financial compensation paid to former PGR employees strengthened their belief that state institutions would solve all problems. The state and state-owned farms acting as welfare providers, which organised one's everyday life, including housing matters, child care and food supply, meant that PGR workers and their family members did not have to show any initiative, such as trying to solve their own problems (PsykPiotrowska, 1998). The low level of education as well as narrow qualifications gained while doing simple, specifically defined jobs proved to be inadequate to perform well in a market economy (Lawryniuk, 2001).

\section{METHODOLOGY}

The main purpose of this study has been to diagnose attitudes among residents of rural areas formerly occupied by state-owned farms (PGR) in the Province of Warmia and Mazury (województwo warmińsko-mazurskie), and to identify determinants of such attitudes.

The research of attitudes among residents of rural areas formerly occupied by state-owned farms (PGR) was based on a survey method, according to the methodology developed at the Department of Economic Policy, the Faculty of Economic Sciences, the University of Warmia and Mazury in Olsztyn. The main research tool was a questionnaire prepared by the research authors to interview the respondents.

The survey was completed by 162 persons, all living in villages formerly occupied by state-owned farms ${ }^{2}$ in the Province of Warmia and Mazury and in eight towns of the same province where the total area of a local state farm made up a high share in the total area prior to the state transformation. Respondents used to state-owned farms employees or members of their families.

Analysis of entrepreneurship was based on the entrepreneurship rate expressed as the number of business entities registered in the REGON system per 10000 working age residents.

\section{ENTREPRENEURSHIP OF RESIDENTS OF RURAL AREAS FORMELY OCCUPIED BY STATE-OWNED FARMS IN THE LIGHT OF OUR RESEARCH}

The Province of Warmia and Mazury (województwo warmińsko-mazurskie) is among the most backward regions in Poland and in the European Union. The main causes are relatively poor technical and road infrastructure, few industrial facilities and a low level of investment inputs in the region that has persisted for many years now. Despite considerable disproportions, following Poland's accession to the EU, the Province of Warmia and Mazury gained 11 per cent points higher in the average GDP per capita relative to the EU-28 countries between the years 2004 and 2015 (38\%-2004 vs 49\% - 2015) (Periodic report ...2018).

In 2017, no more than 2.91\% (125 377) of all business entities listed in the REGON register in Poland conducted their activity in this province. The calculated value of entrepreneurship index ${ }^{3}$ in 2010-2017 in the Province of Warmia and Mazury equalled 1314.45 business entities per 10,000 working age residents $\left(13^{\text {th }}\right.$ place among all 16 provinces in Poland) (fig. 1). When analysing the entrepreneurship index (EI) relative to its mean value for the whole country (1 606.69), as many as 93.10\% (108) municipalities of the Province of Warmia and Mazury scored below this value. The lowest values of the EI were determined for the poorest rural municipalities, in areas formerly owned by state farms, characterised by a low rate of employment, undesirable demographic changes and a low level of business activity among the residents (Marks-Bielska, Opalach, 2019).

The study carried out among former state farm employees and their families shows that as many as $64.20 \%$ of the respondents became unemployed and received unemployment benefits after the dissolution of state farms. In this group, no more than $47.12 \%$ were actively seeking new employment, being aware that the unemployment benefits were granted for a specified period of time. Most of the surveyed persons thought that finding a new job after the liquidation of a local state-owned farm was difficult (62.96\% of replies), and some indicated that it was even impossible (4.94\%). The majority of respondents presented a low level of education, such as primary school (36.42\%), vocational school $(35.18 \%)$, secondary education $(23.46 \%)$, while only $4.94 \%$ gained higher education.

\footnotetext{
${ }^{1}$ This attitude is widespread among employees of former state farms. It arises from their strong dependence on the employer in the past, geographical location of housing estates in which they live, and being isolated from the surroundings in the past.

${ }^{2}$ Housing estates attached to former state-owned farms were built and maintained to provide state farm workers and their families with housing. In total, over 6 thousand such housing estates were built while state-owned farms operated, and they were inhabited by around 2 million people.

${ }^{3}$ Number of companies registered in the REGON per 10,000 working age inhabitants.
} 
In order to explore entrepreneurial attitudes among the respondents, they were asked to interpret what in their opinion being entrepreneurial meant. Over $70 \%$ equated the concept with setting up own business. Other responses were distributed quite evenly, as $14.81 \%$ respondents understood the notion of entrepreneurship as reaching subsequent steps in a professional career, and $14.20 \%$ each as expanding economic activity or possessing specific features of character (fig. 2).

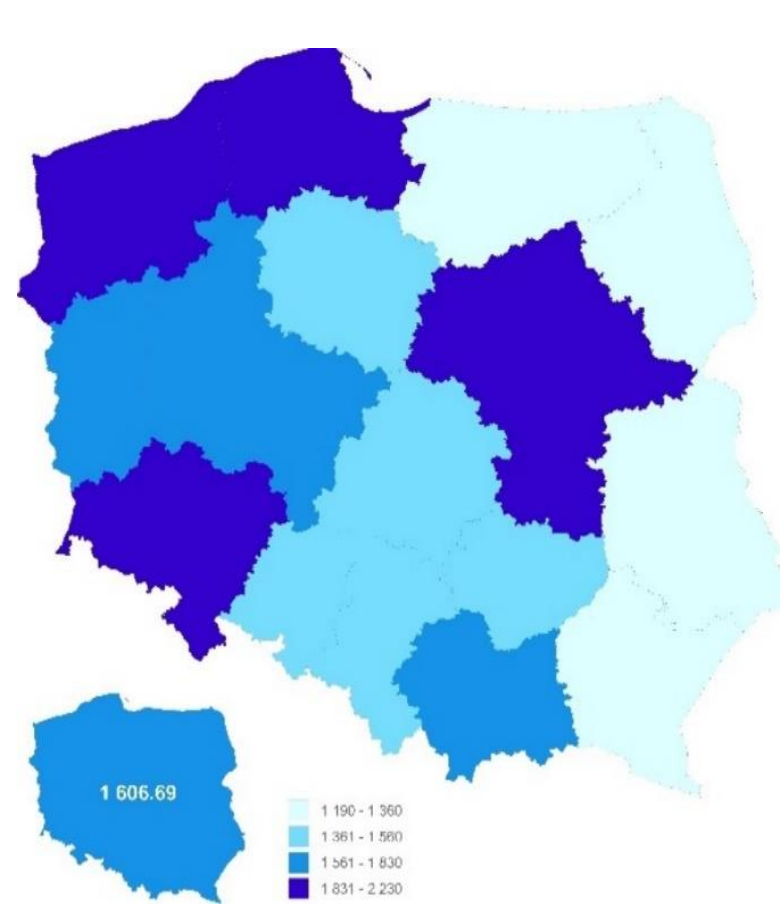

Figure 1. The average value of entrepreneurship rates in individual provinces in Poland between 2010 and 2017

Source: Marks-Bielska, Opalach, 2019

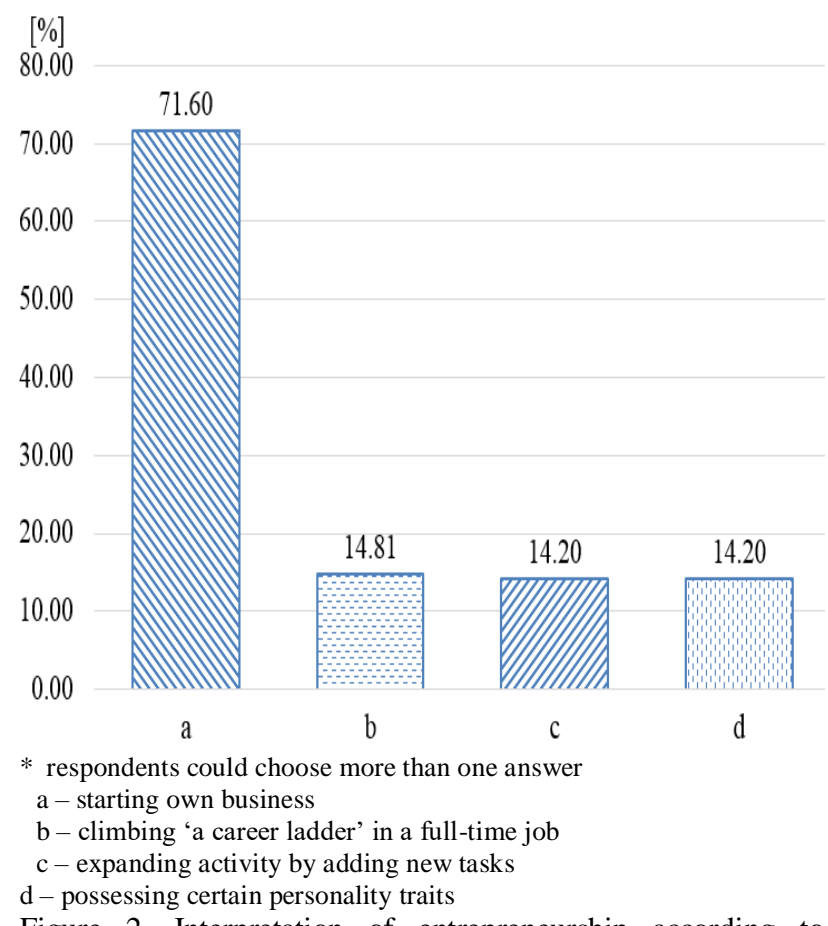

Figure 2. Interpretation of entrepreneurship according to respondents, inhabitants of areas formerly occupied by state farms

Source: the authors, based on research results

Despite the difficult situation on the labour market after the dissolution of PGR, only $12.35 \%$ of the respondents tried to start their own business. The major determinants of such a low level of entrepreneurship among the respondents, were, in their opinion: lack of own funds- $49.38 \%$, excessively high interest rates on bank loans $-14.81 \%$, and lack of self-confidence $-14.20 \%$. One in ten respondents $(11.11 \%)$ pointed to the lack of support on behalf of state administration as the key reason for not trying to set up own business.

The questions aiming to explore the expectations of inhabitants of former state farm housing estates with respect to public administration show that over $80 \%$ of the respondents consider providing financial support as the most significant measure taken by the state. The second most frequent indication was organisation of training sessions $-14.20 \%$. Fewer respondents pointed to the facilitation of bank loan taking $-6.79 \%$ and other forms of help $-5.56 \%$ (fig. 3).

a

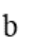

$$
\mathrm{b}
$$

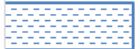

c

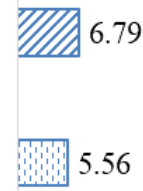

0.00 79 5.56

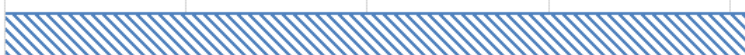

82.10 14.20 (4.20

20.00

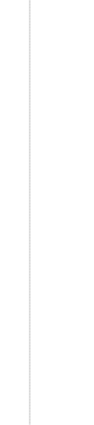

40.00

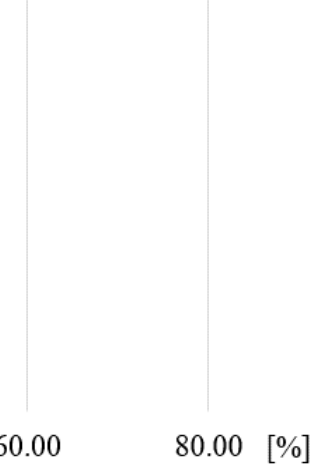

60.00
$80.00[\%]$

*respondents could choose more than one answer

$\mathrm{a}$ - direct financial support

$\mathrm{b}$ - conducting trainings

$\mathrm{c}$ - facilitation of taking bank loans (collaterals, help with required paperwork)

$\mathrm{d}$ - others

Figure 3. Types of help expected by the populations living in former state farm areas from public institutions Source: the authors, based on research results 
The research results dealing with entrepreneurial attitudes presented in this paper, as well as previous studies by other authors concerning former state farm communities (Psyk-Piotrowska, 1998; Kawczyńska-Butrym, 2001; Niedzielski, Domańska, 2001; Marks-Bielska, 2005) confirm the marginal interest in undertaking own economic activity among the populations inhabiting rural areas previously occupied by state-owned farms.

\section{CONCLUSION}

Theories of entrepreneurship point to the need for a multi-faceted approach to analysing the notion of entrepreneurship and the figure of an entrepreneur. The complex nature of entrepreneurship means that economic sciences will not suffice to conduct insightful studies. To gain thorough understanding of this phenomenon, it is necessary to combine research results and achievements from various domains of science.

The state transformation in Poland initiated in the 1990s was a time of significant changes for the Polish countryside. This historic process, leading to fundamental economic, social and political changes, established a new framework for rural areas, including ones which used to belong to state-owned farms. Having worked for many years at state-owned farms, the residents of rural areas formerly occupied by PGR developed specific personal traits and life attitudes, negating the spirit of enterprise, for example they nurtured a sense of entitlement, leading to the so-called learned hopelessness.

The survey designed to analyse entrepreneurial attitudes among the communities living in rural areas previously owned by state farms shows that $71.60 \%$ interpret being entrepreneurial as being able to start one's own business. Despite the difficult situation on the labour market, only $12.35 \%$ of the respondents made an attempt to set up own company after the dissolution of state-owned farms. The main determinant of such a low level of entrepreneurship among the respondents was, in their opinion, the lack of own funds $-49.38 \%$. This response was mirrored when they were asked about expectations towards public administration institutions. $82.10 \%$ of the respondents claimed that the state should be responsible for providing direct financial support.

Although 30 years have already passed since the beginning of the state transformation in Poland, rural areas formerly occupied by state-owned farm are still a place where many complex economic and social problems appear. Specific personal traits, narrow qualifications and low level of education are the principal factors that determine the marginal level of entrepreneurship among people living in these areas. Moreover, the poorly developed transportation infrastructure and underinvestment persisting for many years make the rural areas previously managed as state-owned farms demonstrate the lowest level of entrepreneurship in the whole country.

\section{REFERENCES}

1. Acs Z. J., Desai S., Hessels J. 2008. Entrepreneurship, economic development and institutions. Small Business Economics, Vol. 31(3), pp. 219-234. https://doi.org/10.1007/s11187-008-9135-9

2. Audretsch D. B. 2001. What's New about the New Economy? Sources of Growth in the Managed and Entrepreneurial Economies. Industrial and Corporate Change, Vol. 10(1), pp. 267-315. https://doi.org/10.1093/icc/10.1.267

3. Baumgartner D., Putz M., Seidl I. 2013. What Kind of Entrepreneurship Drives Regional Development in European Non-core Regions? A Literature Review on Empirical Entrepreneurship Research. European Planning Studies, Vol. 21(8), pp. $1095-1106$. https://doi.org/10.1080/09654313.2012.722937

4. Baumol W. J. 1990. Entrepreneurship: Productive, Unproductive, and Destructive. Journal of Political Economy, Vol. 98 (5), pp. 916-918. https://doi.org/10.1086/261712

5. Cherukara J., Manalel J. 2011. Evolution of entrepreneurship theories through different schools of thought. Proceedings of The Ninth Biennial Conference on Entrepreneurship at EDI, Ahmedabad, pp. 3-6.

6. Huggins R., Thompson P. 2016. Socio-Spatial Culture and Entrepreneurship: Some Theoretical and Empirical Observations. Economic Geography, Vol. 92(3), pp. 269-300. https://doi.org/10.1080/00130095.2016.1146075

7. Kawczyńska-Butrym Z. 2001. Mieszkańcy osiedli byłych pegeerów o swojej sytuacji życiowej [Residents of former state farm housing estates about their living situation]. Studio Poligrafii Komputerowej „SQL” s.c., Olsztyn [in Polish].

8. Ławryniuk W. 2001. Społeczny wymiar transformacji rolnictwa uspołecznionego w Polsce [Social dimension of the transformation of the non-private agricultural sector]. Agroprzemiany, No. 4 (102), pp. 7-10 [in Polish].

9. Marks-Bielska R. 2005. Byli pracownicy PGR jako „przegrani” transformacji ustrojowej [Former state-owned farm workers as 'losers' of the state transformation]. Polityka Spoleczna, Warszawa, Vol. 376 (7), pp. 9-12 [in Polish].

10. Marks-Bielska R. 2014. Factors Affecting Farmland Management in Poland in 1992-2012 in the Institutional Context. Proceedings of International Scientific Conference „Economic Sciences for Rural Development 2014”, Latvia University of Agriculture, Jelgava, No 35, pp. 189-198.

11. Marks-Bielska R. 2017. The Role Of Local Authorities In Creating Conditions For The Development of Economic Activities: A Case Study Of Rural Municipalities In Poland. Proceedings Of The 8th International Scientific Conference „,Rural Development 2017”, Aleksandras Stulginskis University, pp. 1179-1183. https://doi.org/10.15544/RD.2017.249

12. Marks-Bielska R., Opalach D. 2019. Differences in the level of entrepreneurship among municipalities of the Province of Warmia and Mazury in Poland. Acta Sci. Pol. Oeconomia, Warszawa, Vol. 18 (1), pp. 53-62. https://doi.org/10.22630/ASPE.2019.18.1.6

13. Milczarek D. 2002. Privatisation as a Process of Institutional Change. The Case of State Farms in Poland. Shaker Verlag. Aachen 2002.

14. Niedzielski E., Domańska L. 2001. Sytuacja mieszkańców terenów popegeerowskich w świetle badań, Materiały konferencyjne: Aktywizacja społeczno-zawodowa mieszkańców terenów byłych PGR [Situation of residents of former state farm areas in the 
light of research. Conference proceedings: Social and vocational activisation of inhabitants of former state farm areas]. 27.03.2001 r., Olsztyn [in Polish].

15. Novak M. 1993. The Catholic Ethic and the Spirit of Capitalism. New York, Toronto, The Free Press, XV.

16. Raport okresowy $\mathrm{nr}$ XVI z realizacji strategii rozwoju społeczno-gospodarczego województwa warmińsko-mazurskiego do 2025 r. w latach 2016-2017 [Periodic report No. XVI on the implementation of the strategy of socio-economic development of the Province Warmia and Mazury until 2025 in 2016-2017]. Marshal's Office of the Province of Warmia and Mazury, 2018, Olsztyn [in Polish].

17. Psyk-Piotrowska E. 1998. Bezrobocie i pauperyzacja środowisk dawnych PGR w Polsce [Unemployment and impoverishment of communities of former state-owned farms in Poland]. Wieś i Rolnictwo, No. 3 (100), pp. 132-143 [in Polish].

18. Rispas S. 1998. Towards an Interdisciplinary Theory of Entrepreneurship. Small Business Economics, Vol. 10 (2), pp. $109-112$.

19. Vaillant Y., Lafuente E. 2007. Do different institutional frameworks condition the influence of local fear of failure and entrepreneurial examples over entrepreneurial activity? Entrepreneurship \& Regional Development, Vol. 19(4), pp. 313-320. https://doi.org/10.1080/08985620701440007

20. Williams N., Vorley T. 2015. Institutional asymmetry: How formal and informal institutions affect entrepreneurship in Bulgaria. International Small Business Journal: Researching Entrepreneurship, Vol. 33(8), pp. 840-861. https://doi.org/10.1177/0266242614534280

21. Williams N., Vorley T., Williams C. C. 2017. Entrepreneurship and institutions: The causes and consequences of institutional asymmetry. London, New York: Rowman \& Littlefield International.

22. Wilkin J. 2007. Przemiany na obszarach wiejskich w Polsce w okresie transformacji systemowej i integracji europejskiej [Transformations in rural areas in Poland during the state transformation and integration with the EU]. [In:] Kłodziński, M., Błąd M., Wilczyński R., Odnowa wsi w integrującej się Europie [Renewal of the countryside in integrating Europe]. Warszawa, Instytut Rozwoju Wsi i Rolnictwa PAN, pp. 37-49 [in Polish]. 